\title{
PERJANJIAN BANGUN GUNA SERAH ANTARA PEMERINTAH KABUPATEN/KOTA DAN PERSEROAN TERBATAS
}

\author{
Urip Santoso* \\ Departemen Hukum Administrasi Fakultas Hukum Universitas Airlangga \\ Jl. Dharmawangsa Dalam Selatan, Surabaya, Jawa Timur 60286
}

\begin{abstract}
Status of land that can be controlled by the local government is the right of use and the right of management. The right of management can be the object of Agreement on Build, Operate, and Transfer between the local government and the company. Then, the company gets the right of management through the Government Decision which is written up in to a form of Decree of Granting Rights. In the last term of the Agreement on Build, Operate, and Transfer, the land and the building with all support facilities submitted by company to the local government.
\end{abstract}

Keywords: land, build operate transfer, certificate.

\section{Intisari}

Status tanah yang dapat dikuasai oleh pemerintah kabupaten/kota adalah hak pakai dan hak pengelolaan. Tanah yang berstatus hak pengelolaan pemerintah kabupaten/kota yang dapat menjadi objek Perjanjian Banguna Guna Serah dengan Perseroan Terbatas. Perseroan Terbatas mendapatkan hak guna bangunan atas tanah hak pengelolaan melalui Penetapan Pemerintah dalam bentuk Surat Keputusan Pemberian Hak. Pada akhir masa Perjanjian Banguna Guna Serah, tanah dan bangunan beserta sarana pendukungnya diserahkan oleh Perseroan Terbatas kepada pemerintah kabupaten/kota.

Kata Kunci: tanah, bangun guna serah, sertifikat.

\section{Pokok Muatan}

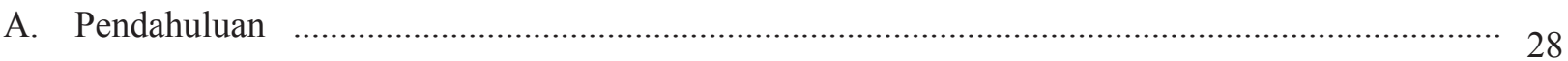

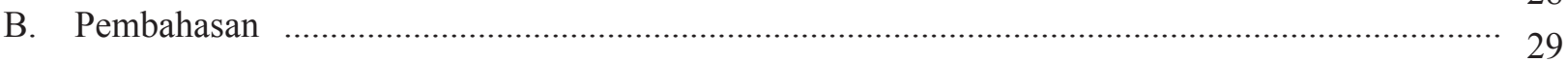

1. Status Hak Atas Tanah yang Menjadi Objek Perjanjian Bangun Guna Serah........................... 29

2 Perolehan Hak Atas Tanah oleh Perseroan Terbatas yang Berasal dari Perjanjian

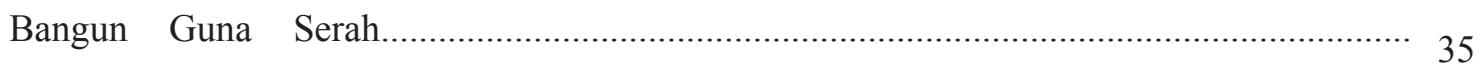

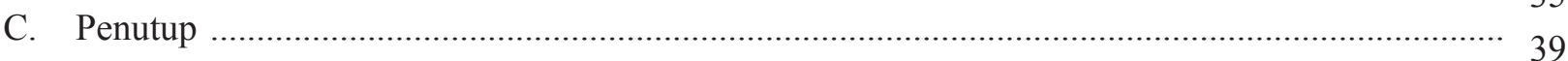

* Alamat korespondensi: urip_sts@yahoo.com 


\section{A. Pendahuluan}

Tanah yang ada di seluruh wilayah Republik Indonesia merupakan karunia Tuhan Yang Maha Esa bagi bangsa Indonesia dan merupakan kekayaan nasional. Oleh karena itu, tanah yang ada harus dipergunakan, diusahakan, dimanfaatkan, dipelihara, dilindungi, dan dikelola dengan sebaikbaiknya dan harus dapat mewujudkan sebesar-besar kemakmuran rakyat, baik bagi generasi sekarang maupun generasi yang akan datang. Dalam mempergunakan dan/atau mengusahakan tanah tidak hanya memperhatikan kepentingan generasi sekarang, juga harus memperhatikan kepentingan generasi yang akan datang.

Kegiatan yang dilakukan oleh pemerintah, pemerintah provinsi, pemerintah kabupaten/kota, perusahaan swasta, dan masyarakat pada umumnya tidak dapat lepas dari kebutuhan akan tanah disebabkan kegiatan yang dilakukannya pada umumnya berada di atas tanah. Tanah yang ada dapat dipergunakan untuk keperluan mendirikan bangunan, contohnya adalah di atas tanah didirikan bangunan rumah tempat tinggal atau hunian, rumah susun/apartemen, rumah toko (ruko), rumah kantor (rukan), rumah sakit, toko, pasar/plaza/mall, kantor, hotel, pabrik, gudang, gedung pendidikan, gedung peribadatan, gedung olahraga, gedung pertemuan, terminal, pelabuhan, Bandar udara. Tanah juga dapat diusahakan atau dimanfaatkan untuk keperluan pertanian, perikanan, peternakan, dan perkebunan.

Kebutuhan akan tanah untuk kepentingan pemerintah, pemerintah provinsi, pemerintah kabupaten/kota, perusahaan swasta, dan masyarakat pada umumnya terus meningkat dari tahun ke tahun seiring dengan pesatnya pembangunan. Oleh karena itu, untuk memenuhi kebutuhan akan tanah untuk pembangunan diperlukan persediaan tanah. Permasalahannya adalah tanah yang tersedia untuk memenuhi kebutuhan pembangunan sangat terbatas, sehingga dapat terjadi persaingan untuk mendapatkan sebidang tanah. Terbatasnya persediaan tanah membawa konsekuensi harga tanah terus melambung tinggi dan dapat menimbulkan sengketa untuk mendapatkan tanah bagi para pihak yang terkait.
Tanah dalam pengertian yuridis yaitu hak atas tanah dapat dimiliki atau dikuasai oleh perseorangan warga negara Indonesia maupun orang asing yang berkedudukan di Indonesia, badan hukum yang didirikan menurut hukum Indonesia dan berkedudukan di Indonesia, dan badan hukum asing yang mempunyai perwakilan di Indonesia. Dalam Hukum Pertanahan Nasional ditetapkan macam-macam status tanah, yaitu hak milik (HM), hak guna usaha (HGU), hak guna bangunan (HGB), hak pakai (HP), hak sewa untuk bangunan (HSUB), dan hak pengelolaan (HPL). Hak atas tanah tersebut ada yang dikuasai oleh perseorangan dan ada yang dikuasai oleh badan hukum.

Salah satu contoh badan hukum yang didirikan menurut hukum Indonesia dan berkedudukan di Indonesia adalah pemerintah provinsi dan pemerintah kabupaten/kota. Pemerintah provinsi dan pemerintah kabupaten/kota dapat mempunyai kekayaan berupa hak atas tanah. Hak atas tanah diperlukan dalam rangka melaksanakan tugas pokok dan fungsi pemerintah provinsi dan pemerintah kabupaten/kota.

Pemerintah kabupaten/kota merupakan pemerintah daerah yang mempunyai kekayaan berupa hak atas tanah. Hak atas tanah ini ada yang masih berupa tanah kosong, ada juga yang di atas tanah didirikan bangunan untuk kepentingan pemerintah kabupaten/kota. Tanah pemerintah kabupaten/kota yang dipergunakan untuk kepentingannya sendiri, adalah di atas tanah didirikan bangunan gedung kantor bupati/walikota, kantor dinas. kantor kecamatan, kantor kelurahan, rumah sakit/pusat kesehatan masyarakat, rumah dinas, gedung pendidikan, gedung olahraga, gedung peribadatan, gedung pertemuan, gedung Dewan Perwakilan Rakyat Daerah, terminal, pabrik, gudang, pasar.

Tanah yang dikuasai oleh pemerintah kabupaten/kota ada yang masih berupa tanah kosong. Tanah yang berupa tanah kosong tidak mempunyai nilai ekonomis atau nilai ekonomisnya rendah bagi pemerintah kabupaten/kota. Agar tanah kosong ini menjadi bernilai ekonomis tinggi bagi pemerintah kabupaten/kota, maka pemerintah kabupaten/ 
kota dapat mendayagunakan atau mengoptimalkan tanah kosong ini dalam bentuk melaksanakan kerjasama dengan perusahaan swasta. Kerjasama antara pemerintah kabupaten/kota dan perusahaan swasta yang berbentuk Perseroan Terbatas (PT) untuk mempergunakan tanah yang dikuasai oleh pemerintah kabupaten/kota dalam bentuk Perjanjian Banguna Guna Serah (BGS). Melalui Perjanjian Banguna Guna Serah, Perseroan Terbatas diberikan hak untuk mendirikan bangunan gedung di atas tanah yang dikuasai oleh pemerintah kabupaten/kota.

Dari uraian latar belakang masalah di atas, permasalahan yang hendak dikaji dalam tulisan ini, adalah: Pertama, bagaimana status tanah pemerintah kabupaten/kota yang dapat menjadi objek Perjanjian Bangunan Guna Serah?; dan Kedua, bagaimana perolehan hak atas tanah oleh Perseroan Terbatas yang berasal dari Perjanjian Banguna Guna Serah?

\section{B. Pembahasan}

\section{Status Hak Atas Tanah yang Menjadi Ob-} jek Perjanjian Banguna Guna Serah

Hak atas tanah diatur dalam Undang-Undang

No. 5 Tahun 1960 tentang Peraturan Dasar PokokPokok Agraria, atau yang lebih dikenal dengan sebutan Undang-Undang Pokok Agraria (UUPA). Pasal 50 ayat (2) UUPA menyatakan bahwa ketentuan lebih lanjut mengenai hak guna usaha, hak guna bangunan, hak pakai, dan hak sewa Untuk bangunan diatur dengan peraturan perundangan. ${ }^{1}$ Peraturan perundangan yang dimaksudkan oleh Pasal 50 ayat (2) UUPA, adalah Peraturan Pemerintah No. 40 Tahun 1996 tentang Hak Guna Usaha, Hak Guna Bangunan, dan Hak Pakai Atas Tanah.

Hak atas tanah diatur dalam Pasal 4 ayat (1) UUPA disebutkan bahwa atas dasar hak menguasai negara, ditentukan bermacam-macam hak atas permukaan bumi, yang disebut tanah, yang dapat diberikan kepada dan dipunyai oleh orang-orang, baik sendiri maupun bersama-sama dengan orang lain, serta badan-badan hukum. ${ }^{2}$ Hak atas permukaan bumi juga disebut hak atas tanah, yang dapat diberikan kepada dan dipunyai oleh orang-orang, baik sendiri maupun bersama-sama dengan orangorang lain yang berasal dari warga negara Indonesia atau orang asing yang berkedudukan di Indonesia, badan hukum yang didirikan menurut hukum Indonesia dan berkedudukan di Indonesia, dan badan hukum asing yang mempunyai perwakilan di Indonesia.

UUPA tidak memberikan pengertian apa yang dimaksud dengan hak atas tanah. Menurut Urip Santoso, hak atas tanah adalah hak yang memberikan wewenang kepada pemegang haknya untuk menggunakan dan/atau mengambil manfaat dari tanah yang dihaki. Perkataan "menggunakan" mengandung pengertian bahwa hak atas tanah untuk kepentingan mendirikan bangunan, sedangkan perkataan "mengambil manfaat" mengandung pengertian bahwa hak atas tanah untuk kepentingan pertanian, perikanan, peternakan, dan perkebunan. ${ }^{3}$

Hak atas tanah yang disebutkan dalam Pasal 4 ayat (1) UUPA dijabarkan macam haknya dalam Pasal 16 ayat (1) UUPA dan Pasal 53 ayat (1) UUPA. Sri Hajati menyatakan bahwa macam-macam hak atas tanah berdasarkan Pasal 16 dan Pasal 53 UUPA dibedakan menjadi tiga kelompok, yaitu: Pertama, hak atas tanah yang bersifat tetap, macam haknya adalah hak milik, hak guna usaha, hak guna bangunan, hak pakai, hak sewa untuk bangunan, hak membuka tanah, dan hak memungut hasil hutan; Kedua, hak atas tanah yang akan ditetapkan dengan undang-undang; dan Ketiga, hak atas tanah yang bersifat sementara, macam haknya adalah hak gadai, hak usaha bagi hasil, hak menumpang, dan hak sewa tanah pertanian. ${ }^{4}$

Pasal 4 ayat (2) UUPA menetapkan bahwa pemegang hak atas tanah mempunyai wewenang untuk mempergunakan tanah yang bersangkutan, demikian pula tubuh bumi, air, dan ruang yang ada di atasnya sekedar diperlukan untuk kepentingan

Pasal 50 ayat (2) Undang-Undang No. 5 Tahun 1960 tentang Peraturan Dasar Pokok-Pokok Agraria (Lembaran Negara Republik Indonesia Tahun 1960 Nomor 104, Tambahan Lembaran Negara Republik Indonesia Nomor 2043).

Pasal 4 ayat (1) Undang-Undang No. 5 Tahun 1960 tentang Peraturan Dasar Pokok-Pokok Agraria (Lembaran Negara Republik Indonesia Tahun 1960 Nomor 104, Tambahan Lembaran Negara Republik Indonesia Nomor 2043).

Urip Santoso, 2012, Hukum Agraria Kajian Komprehensif, Kencana Prenada Media, Jakarta, hlm. 84.

Sri Hajati, "Retrukturisasi Hak Atas Tanah Dalam Rangka Pembaruan Hukum Agraria Nasional”, Pidato, Penerimaan Jabatan Guru Besar pada Universitas Airlangga, Surabaya, 5 Maret 2005. 
yang langsung berhubungan dengan penggunaan tanah itu dalam batas-batas menurut UUPA. ${ }^{5}$ Pemegang hak atas tanah tidak hanya berwenang mempergunakan tanah untuk kepentingan mendirikan bangunan atau kepentingan pertanian, juga mempunyai wewenang mempergunakan tubuh bumi (di bawah permukaan bumi), air, dan ruang yang ada di atas tanah sekedar diperlukan untuk kepentingan yang langsung berhubungan dengan penggunaan tanah itu.

Yang dapat mempunyai hak atas tanah, dikenal dengan sebutan subjek hak atas tanah sebagai subjek hukum. Pengertian subjek hukum menurut R. Soeroso, adalah sesuatu yang menurut hukum berhak/berwenang untuk melakukan perbuatan hukum atau siapa yang mempunyai hak dan cakap untuk bertindak dalam hukum, sesuatu pendukung hak yang menurut hukum berwenang/berkuasa bertindak menjadi pendukung hak, dan segala sesuatu yang menurut hukum mempunyai hak dan kewajiban. ${ }^{6}$ Sependapat dengan R. Soeroso, Sudikno Mertokusumo menyatakan bahwa subjek hukum adalah segala sesuatu yang dapat memperoleh hak dan kewajiban. ${ }^{7}$ Subjek hukum dapat dibedakan atas dua macam apabila dilihat dari segi hakikatnya, yaitu manusia/orang (natuurlijke person) dan badan hukum (rechts persoon). ${ }^{8}$ Subjek hak atas tanah adalah perseorangan dan badan hukum. Secara terperinci, subjek hak atas tanah adalah warga negara Indonesia, orang asing yang berkedudukan di Indonesia, lembaga negara, departemen, lembaga pemerintah non departemen, pemerintah provinsi, pemerintah kabupaten/kota, pemerintahan desa, badan otorita, Badan Usaha Milik Negara, Badan Usaha Milik Daerah, perusahaan asing yang mempunyai perwakilan di Indonesia, Perseroan Terbatas, perwakilan negara asing, perwakilan badan internasional, badan keagamaan, dan badan sosial. Salah satu pemegang hak atas tanah (subjek hak atas tanah) adalah pemerintah kabupaten/kota. Pemerintah kabupaten/kota dapat mempunyai hak atas tanah tertentu yang ditetapkan oleh peraturan perundang-undangan di bidang pertanahan. Dalam peraturan perundang-undangan ditetapkan bahwa hak atas tanah yang dapat dikuasai oleh pemerintah kabupaten/kota, adalah:

\section{a. Hak Pakai}

Hak pakai disebutkan dalam Pasal 16 ayat (1) huruf d UUPA. Ketentuan hak pakai dijabarkan dalam Pasal 41 sampai dengan Pasal 43 UUPA. Pasal 50 ayat (2) UUPA menetapkan bahwa ketentuan lebih lanjut mengenai hak pakai diatur dengan peraturan perundangan. Peraturan perundangan yang dimaksudkan Pasal 50 ayat (2) UUPA adalah Peraturan Pemerintah No. 40 Tahun 1996. Secara khusus, hak pakai diatur dalam Pasal 39 sampai dengan Pasal 58 Peraturan Pemerintah No. 40 Tahun 1996.

Pengertian Hak Pakai disebutkan dalam Pasal 41 ayat (1) UUPA, yaitu: "Hak pakai adalah hak untuk menggunakan atau memungut hasil dari tanah yang dikuasai langsung oleh negara atau tanah milik orang lain, yang memberi wewenang dan kewajiban yang ditentukan dalam keputusan pemberiannya oleh pejabat yang berwenang memberikannya atau dengan perjanjian dengan pemilik tanahnya, yang bukan perjanjian sewa menyewa atau perjanjian pengolahan tanah, segala sesuatu asal tidak bertentangan dengan jiwa dan ketentuan-ketentuan Undang-Undang ini". ${ }^{9}$ Dari ketentuan Pasal 41 UUPA dapat dijelaskan ciri-ciri hak pakai, adalah: (a) Wewenang pemegang hak pakai terhadap tanahnya adalah mempergunakan tanahnya untuk kepentingan mendirikan bangunan, yaitu dapat dilihat dari perkataan "menggunakan tanahnya", juga dapat dipergunakan untuk kepentingan pertanian, perikanan, peternakan, dan perkebunan, yaitu dilihat dari perkataan "memungut hasil dari

Pasal 4 ayat (2) Undang-Undang Nomor 5 Tahun 1960 tentang Peraturan Dasar Pokok-Pokok Agraria (Lembaran Negara Republik Indonesia Tahun 1960 Nomor 104, Tambahan Lembaran Negara Republik Indonesia Nomor 2043).

R. Soeroso, 1993, Pengantar Ilmu Hukum, Sinar Grafika, Jakarta, hlm. 228.

Sudikno Mertokusumo, 2008, Mengenal Hukum Suatu Pengantar, Liberty, Yogyakarta, hlm. 67.

Ishaq, 2008, Dasar-Dasar Ilmu Hukum, Sinar Grafika, Jakarta, hlm. 47.

Pasal 41 ayat (1) Undang-Undang Nomor 5 Tahun 1960 tentang Peraturan Dasar Pokok-Pokok Agraria (Lembaran Negara Republik Indonesia Tahun 1960 Nomor 104, Tambahan Lembaran Negara Republik Indonesia Nomor 2043). 
tanah"; (b) asal tanah hak pakai adalah tanah yang dikuasai langsung oleh negara dan tanah hak milik; (c) cara terjadinya hak pakai adalah untuk hak pakai yang terjadi pada tanah negara melalui keputusan pemberian hak oleh pejabat yang berwenang, sedangkan hak pakai yang terjadi pada tanah hak milik melalui perjanjian penggunaan tanah antara pemilik tanah dan pemegang hak pakai; (d) Hak pakai tidak boleh terjadi dengan perjanjian sewa menyewa tanah atau perjanjian pengolahan tanah; dan (e) Hak pakai dapat diberikan untuk jangka waktu tertentu, atau selama tanahnya dipergunakan untuk keperluan tertentu.

Pasal 42 UUPA menetapkan bahwa yang dapat mempunyai hak pakai, adalah: (a) Warga Negara Indonesia; (b) Orang asing yang berkedudukan di Indonesia; (c) Badan hukum yang didirikan menurut hukum Indonesia dan berkedudukan di Indonesia; (d) Badan hukum asing yang mempunyai perwakilan di Indonesia. ${ }^{10}$ Pasal 39 Peraturan Pemerintah No. 40 Tahun 1996 menetapkan bahwa yang dapat mempunyai hak pakai, adalah: (a) Warga Negara Indonesia; (b) badan hukum yang didirikan menurut hukum Indonesia dan berkedudukan di Indonesia; (c) departemen, lembaga pemerintah non departemen, dan pemerintah daerah; (d) badan-badan keagamaan dan badan sosial; (e) orang asing yang berkedudukan di Indonesia; (f) badan hukum asing yang mempunyai perwakilan di Indonesia; dan (g) perwakilan negara asing dan perwakilan badan internasional. ${ }^{11}$ Pasal 49 Peraturan Menteri Negara Agraria/Kepala Badan Pertanahan Nasional (Permen Agraria/Kepala BPN) No. 9 Tahun 1999 tentang Tata Cara Pemberian dan Pembatalan Hak Atas Tanah Negara dan hak pengelolaan menetapkan bahwa hak pakai diberikan kepada: (a) Warga Negara
Indonesia; (b) orang asing yang berkedudukan di Indonesia; (c) instansi pemerintah; (c) badan hukum yang didirikan menurut hukum Indonesia dan berkedudukan di Indonesia; dan (d) badan hukum asing yang mempunyai perwakilan di Indonesia. ${ }^{12}$

Berdasarkan asal tanahnya, hak pakai atas tanah dibagi menjadi 3 (tiga) macam, yaitu hak pakai atas tanah negara, hak pakai atas tanah hak pengelolaan, dan hak pakai atas tanah hak milik. Hak pakai atas tanah negara terjadi dengan Surat Keputusan Pemberian Hak (SKPH) yang diterbitkan oleh Kepala Badan Pertanahan Nasional RI atau pejabat Badan Pertanahan Nasional RI yang diberikan pelimpahan kewenangan memberikan hak atas tanah, Hak Pakai atas tanah Hak Pengelolaan terjadi dengan Surat Keputusan Pemberian Hak (SKPH) oleh Kepala Kantor Pertanahan Kabupaten/Kota atas usul pemegang hak Pengelolaan, dan hak pakai atas tanah hak milik terjadi dengan Akta Pemberian Hak Pakai atas tanah hak milik yang dibuat oleh Pejabat Pembuat Akta Tanah (PPAT). Hak pakai atas tanah negara dan hak pakai atas tanah hak pengelolaan terjadi melalui permohonan pemberian hak atas tanah, sedangkan hak pakai atas tanah hak milik terjadi melalui perjanjian antara pemilik tanah dan pemegang hak pakai.

Hak pakai atas tanah negara dan hak pakai atas tanah hak pengelolaan diterbitkan sertifikat sebagai tanda bukti haknya oleh Kepala Kantor Pertanahan Kabupaten/ Kota, sedangkan hak pakai atas tanah hak milik tidak diterbitkan sertifikat. Salah satu subjek (pemegang) hak pakai adalah pemerintah daerah, yaitu pemerintah provinsi dan pemerintah kabupaten/kota. Hak pakai atas tanah yang dipunyai oleh pemerintah kabupaten/kota, tanahnya berasal dari tanah negara. Terjadinya hak pakai atas tanah yang

10 Pasal 42 Undang-Undang Nomor 5 Tahun 1960 tentang Peraturan Dasar Pokok-Pokok Agraria (Lembaran Negara Republik Indonesia Tahun 1960 Nomor 104, Tambahan Lembaran Negara Republik Indonesia Nomor 2043).

1 Pasal 39 Peraturan Pemerintah Nomor 40 Tahun 1996 tentang Hak Guna Usaha, Hak Guna Bangunan, dan Hak Pakai Atas Tanah (Lembaran Negara Republik Indonesia Tahun 1996 Nomor 58, Tambahan Lembaran Negara Republik Indonesia Nomor 3643).

12 Pasal 49 Peraturan Menteri Negara Agraria/Kepala Badan Pertanahan Nasional Nomor 9 Tahun 1999 tentang Tata Cara Pemberian dan Pembatalan Hak Atas Tanah Negara dan Hak Pengelolaan. 
dipunyai oleh pemerintah kabupaten/kota melalui permohonan pemberian hak atas tanah negara kepada Kepala Badan Pertanahan Nasional RI melalui Kepala Kantor Pertanahan Kabupaten/Kota setempat. Sebagai tanda bukti hak pakai atas tanah yang dipunyai oleh pemerintah kabupaten/kota diterbitkan sertifikat oleh Kepala Kantor Pertanahan Kabupaten/Kota setempat.

A.P. Parlindungan menyatakan bahwa hak pakai yang dipunyai oleh badan hukum publik disebut hak pakai publik ada right to use, yaitu menggunakannya untuk waktu yang tidak terbatas selama pelaksanaan tugas, namun tidak ada right of disposal, yang dimaksud disini adalah tidak dapat dialihkan dalam bentuk apapun kepada pihak ketiga dan juga tidak dapat dijadikan objek hak tanggungan. ${ }^{13}$

\section{b. Hak Pengelolaan}

Istilah hak pengelolaan tidak disebutkan dalam UUPA, UUPA hanya menyebut pengelolaan dalam Penjelasan Umum Angka II Nomor 2 UUPA, yaitu: "Negara dapat memberikan tanah yang demikian itu kepada seseorang atau badan hukum dengan sesuatu hak menurut peruntukan dan keperluannya, misalnya hak milik, hak guna usaha, hak guna bangunan, hak pakai, atau memberikannya dalam pengelolaan (garis bawah penulis) kepada sesuatu badan penguasa (departemen, jawatan atau daerah swatantra) untuk digunakan bagi pelaksanaan tugasnya masingmasing". ${ }^{14}$

A.P. Parlindungan menyatakan bahwa istilah Hak Pengelolaan diambil dari Bahasa Belanda, yaitu beheersrecht, yang diterjemahkan Hak Penguasaan. ${ }^{15}$ Sependapat dengan A.P. Parlindungan, Supriadi menya- takan bahwa perkataan hak pengelolaan sebenarnya berasal dari terjemahan Bahasa Belanda yang berasal dari kata beheersrecht berarti hak penguasaan. Hak Penguasaan diatur dalam Peraturan Pemerintah No. 8 Tahun 1953 tentang Hak Penguasaan Atas Tanah Negara. ${ }^{16}$ Maria S.W. Sumardjono menyatakan bahwa Peraturan Pemerintah No. 8 Tahun 1953 mengatur hak penguasaan sebagai terjemahan dari beheersrecht atas tanah-tanah negara. ${ }^{17}$

Untuk pertama kalinya, istilah hak pengelolaan disebutkan dalam Pasal 2 Peraturan Menteri Agraria No. 9 Tahun 1965 tentang Pelaksanaan Konversi Hak Penguasaan Atas Tanah Negara dan Ketentuan-Ketentuan tentang Kebijaksanaan Selanjutnya, yaitu: "Jika hak penguasaan atas tanah negara yang diberikan kepada departemen-departemen, direktorat-direktorat, dan daerah-dae-rah swatantra, selain dipergunakan untuk kepentingan instansi-instansi itu sendiri, dimaksudkan untuk dapat diberikan dengan sesuatu hak kepada pihak ketiga, maka hak penguasaan atas tanah negara tersebut dikonversi menjadi Hak Pengelolaan". ${ }^{18}$

Dengan Peraturan Menteri Agraria No. 9 Tahun 1965 menunjukkan bahwa hak pengelolaan lahir tidak didasarkan pada Undang-Undang, melainkan didasarkan oleh Peraturan Menteri Agraria. Seyogyanya, suatu hak yang di dalamnya diatur tentang hak, kewajiban, wewenang, dan larangan bagi pemegang haknya diatur dengan Undangundang, tidak cukup diatur dengan Peraturan Menteri. ${ }^{19}$

Pengertian Hak Pengelolaan disebutkan dalam Pasal 1 angka 2 Peraturan Pemerintah No. 40 Tahun $1996^{20}$ juncto

\footnotetext{
A.P. Parlindungan, "Beberapa Konsep Tentang Hak Atas Tanah”, Majalah Analisis CSIS Tahun XX No. 2, Maret - April 1991.

Penjelasan Umum Angka II Nomor 2 Undang-Undang Nomor 5 Tahun 1960 tentang Peraturan Dasar Pokok-pokok Agraria (Lembaran Negara Tahun 1960 Nomor 104, Tambahan Lembaran Negara Republik Indonesia Nomor 2043) A.P. Parlindungan, 1994, Hak Pengelolaan Menurut Sistem Undang-Undang Pokok Agraria, Mandar Maju, Bandung, hlm. 6. Supriadi, 2007, Hukum Agraria, Sinar Grafika, Maria S.W. Sumardjono, 2007, Kebijakan Pertanahan Antara Regulasi dan Implementasi, Kompas, Jakarta, hlm. 145.

18 Pasal 2 Peraturan Menteri Agraria Nomor 9 Tahun 1965 tentang Pelaksanaan Konversi Hak Penguasaan Atas Tanah Negara dan Ketentuanketentuan tentang Kebijaksanaan Selanjutnya.

19 Urip Santoso, "Eksistensi Hak Pengelolaan Dalam Hukum Tanah Nasional”, Jurnal Mimbar Hukum, Vol. 24, No. 2, Juni 2012.

20 Pasal 1 angka 2 Peraturan Pemerintah Nomor 40 Tahun 1996 tentang Hak Guna Usaha, Hak Guna Bangunan, dan Hak Pakai Atas Tanah (Lembaran Negara Republik Indonesia Tahun 1996 Nomor 58, Tambahan Lembaran Negara Republik Indonesia Nomor 3643 ).
} 
Pasal 1 angka 4 Peraturan Pemerintah No. 24 Tahun 1997 tentang Pendaftaran Tanah ${ }^{21}$ juncto Pasal 1 angka 2 Peraturan Pemerintah No. 11 Tahun 2010 tentang Penertiban dan Pendayagunaan Tanah Terlantar, ${ }^{22}$ yaitu hak menguasai negara atas tanah, yang kewenangan pelaksanaan sebagian dilimpahkan kepada pemegang haknya. Pengertian yang lebih lengkap mengenai Hak Pengelolaan disebutkan dalam Pasal 2 ayat (3) huruf f Undang-Undang No. 20 Tahun 2000 tentang Perubahan Atas Undang-undang Nomor 21 Tahun 1997 tentang Bea Perolehan Hak Atas Tanah dan Bangunan ${ }^{23}$ juncto Pasal 1 Peraturan Pemerintah No. 112 Tahun 2000 tentang Pengenaan Bea Perolehan Hak Atas Tanah dan Bangunan karena Pemberian Hak Pengelolaan, ${ }^{24}$ yaitu hak menguasai negara atas tanah, yang kewenangan pelaksanaan sebagian dilimpahkan kepada pemegang haknya, untuk merencanakan peruntukan dan penggunaan tanah, menggunakan tanah untuk kepentingan pelaksanaan tugasnya, dan menyerahkan bagian-bagian tanah tersebut kepada pihak ketiga.

Hak Pengelolaan diberikan kepada badan hukum Pemerintah, baik yang bergerak dalam pelayanan publik (public service) maupun bisnis (business), yaitu:

a) Pasal 5 Peraturan Menteri Agraria No. 9 Tahun 1965

Hak Pengelolaan diberikan kepada Departemen, Direktorat, dan Daerah Swatantra. ${ }^{25}$

b) Pasal 1 huruf b Peraturan Menteri Agraria No. 1 Tahun 1966 tentang Pendaftaran Hak Pakai dan Hak

\section{Pengelolaan}

Hak Pengelolaan diberikan kepada Departemen, Direktorat, dan Daerah Swatantra. ${ }^{26}$

c) Pasal 29 Peraturan Menteri Dalam Negeri No. 5 Tahun 1974 tentang Ketentuan-ketentuan Mengenai Penyediaan dan Pemberian Tanah Untuk Keperluan Perusahaan

Hak Pengelolaan dapat diberikan kepada Perusahaan Pembangunan Perumahan yang seluruh modalnya berasal dari Pemerintah dan/atau Pemerintah Daerah, Industrial Estate yang seluruh modalnya dari Pemerintah yang berbentuk Perusahaan Umum (Perum) dan Perusahaan Perseroan (Persero), dan dari Pemerintah Daerah yang berbentuk Perusahaan Daerah (PD). ${ }^{27}$

d) Pasal 67 Permen Agraria/Kepala BPN No. 9 Tahun 1999

Badan-badan hukum yang dapat diberi Hak Pengelolaan adalah instansi Pemerintah termasuk Pemerintah Daerah, Badan Usaha Milik Negara (BUMN), Badan Usaha Milik Daerah (BUMD), PT Persero, Badan Otorita, dan badan hukum Pemerintah lainnya yang ditunjuk oleh Pemerintah. ${ }^{28}$

Pada mulanya, berdasarkan Peraturan Menteri Agraria No. 9 Tahun 1965, Hak Pengelolaan terjadi melalui penegasan konversi yang berasal dari hak penguasaan atas tanah negara. Dalam perkembangannya, berdasarkan Peraturan Menteri Dalam Negeri No. 5 Tahun 1974 tentang Ketentuan-ketentuan Mengenai Tata Cara Pemberian Hak Atas Tanah, yang dinyatakan tidak berlaku lagi oleh Permen Agraria/Kepala BPN No. 9 Tahun 1999, Hak Pengelolaan terjadi melalui permohonan pemberian hak atas tanah negara.

21 Pasal 1 angka 4 Peraturan Pemerintah Nomor 24 Tahun 1997 tentang Pendaftaran Tanah (Lembaran Negara Republik Indonesia Tahun 1997 Nomor 59, Tambahan Lembaran Negara Republik Indonesia Nomor 3696).

22 Pasal 1 angka 2 Peraturan Pemerintah Nomor 11 Tahun 2010 tentang Penertiban dan Pendayagunaan Tanah Terlantar (Lembaran Negara Republik Indonesia Tahun 2010 Nomor 16, Tambahan Lembaran Negara Republik Indonesia Nomor 5098).

23 Pasal 2 ayat (3) huruf f Undang-Undang Nomor 20 Tahun 2000 tentang Perubahan atas Undang-Undang Nomor 21 Tahun 1997 tentang BeaPerolehan Hak Atas Tanah dan Bangunan (Lembaran Negara Republik Indonesia Tahun 2000 Nomor 130, Tambahan Lembaran Negara Republik Indonesia Nomor 3988).

24 Pasal 1 Peraturan Pemerintah Nomor 112 Tahun 2000 tentang Pengenaan Bea Perolehan Hak Atas Tanah dan Bangunan Karena Pemberian Hak Pengelolaan (Lembaran Negara Republik Indonesia Tahun 2000 Nomor 214, Tambahan Lembaran Negara Republik Indonesia Nomor 4031).

25 Pasal 5 Peraturan Menteri Agraria Nomor 9 Tahun 1965 tentang Pelaksanaan Konversi Hak Penguasaan Atas Tanah Negara dan KetentuanKetentuan Kebijaksanaan Selanjutnya.

26 Pasal 1 huruf b Peraturan Menteri Agraria Nomor 1 Tahun 1966 tentang Pendaftaran Hak Pakai dan Hak Pengelolaan.

27 Pasal 29 Peraturan Menteri Dalam Negeri Nomor 5 Tahun 1974 tentang Ketentuan-Ketentuan Mengenai Penyediaan dan Pemberian Tanah Untuk Keperluan Perusahaan.

28 Pasal 67 Permen Agraria/Kepala BPN Nomor 9 Tahun 1999 tentang Tata Cara Pemberian dan Pembatalan Pemberian Hak Atas Tanah dan Hak Pengelolaan. 
Permohonan pemberian Hak Pengelolaan yang berasal dari tanah negara diajukan oleh pemohon kepada Kepala Badan Pertanahan Nasional RI melalui Kepala Kantor Pertanahan Kabupaten/Kota setempat. Atas permohonan pemberian Hak Pengelolaan diterbitkan Surat Keputusan Pemberian Hak (SKPH) oleh Kepala Badan Pertanahan Nasional RI. SKPH wajib didaftarkan ke Kantor Pertanahan Kabupaten/Kota setempat untuk diterbitkan Sertifikat Hak Pengelolaan sebagai tanda bukti haknya. Berdasarkan Pasal 2 ayat (3) Undang-undang No. 20 Tahun $2000^{29}$ juncto Pasal 1 Peraturan Pemerintah No. 112 Tahun $2000^{30}$, hak pengelolaan berisikan wewenang, yaitu: (a) merencanakan peruntukan dan penggunaan tanah; (b) mempergunakan tanah untuk kepentingan pelaksanaan tugasnya; dan (c) menyerahkan bagian-bagian tanah hak pengelolaan kepada pihak ketiga dan atau bekerja sama dengan pihak ketiga.

Dari hak pengelolaan dapat diterbitkan hak guna bangunan, hak pakai, dan hak milik. Hak guna bangunan dan hak pakai yang berasal dari tanah hak pengelolaan terjadi melalui SKPH yang diterbitkan oleh Kepala Kantor Pertanahan Kabupaten/Kota setelah didahului oleh pembuatan Perjanjian Penggunaan Tanah (PPT) antara pemegang hak pengelolaan dan calon pemegang hak guna bangunan atau hak pakai. Hak milik yang berasal dari tanah hak pengelolaan terjadi melalui SKPH yang diterbitkan oleh Kepala Kantor Pertanahan Kabupaten/ Kota setelah didahului oleh pelepasan tanah hak pengelolaan oleh pemegang haknya untuk kepentingan calon pemilik tanah.

Pada dasarnya, yang berhak dan berwenang mempergunakan dan atau memanfaatkan hak atas tanah adalah pemegang haknya sendiri. Namun demikian, hak atas tanah dapat dipergunakan dan atau dimanfaatkan oleh orang lain atas persetujuan (izin) dari pemegang haknya dengan perjanjian yang dibuat oleh pemegang hak atas tanah dan orang lain. Penggunaan dan atau pemanfaatan tanah oleh seseorang tanpa persetujuan (izin) pemegang hak atas tanahnya adalah illegal atau tidak sah penggunaan dan atau pemanfaatan tanahnya.

Macam hak atas tanah yang berasal dari penggunaan tanah pihak lain melalui perjanjian penggunaan tanah adalah hak guna bangunan atas tanah hak pengelolaan, hak guna bangunan atas tanah hak milik, hak pakai atas tanah hak pengelolaan, hak pakai atas tanah hak milik, dan hak sewa untuk bangunan. Pemerintah kabupaten/kota mempunyai aset (kekayaan) berupa tanah yang berstatus hak pakai dan hak pengelolaan. Menurut Peraturan Pemerintah No. 6 Tahun 2006 tentang Pengelolaan Barang Milik Negara/Daerah, yang diubah oleh Peraturan Pemerintah No. 38 Tahun 2008 tentang Perubahan Atas Peraturan Pemerintah Nomor 6 Tahun 2006 tentang Pengelolaan Barang Milik Negara/Daerah, dan Peraturan Menteri Dalam Negeri (Permendagri) No. 17 Tahun 2007 tentang Pedoman Teknis Pengelolaan Barang Milik Daerah, barang milik negara/daerah dapat dilakukan pengelolaan dalam bentuk pemanfaatan berupa persewaan, pinjam pakai, kerjasama pemanfaatan, dan bangunan guna serah dan bangun serah guna.

Salah satu macam pemanfaatan barang milik negara/daerah adalah bangun guna serah. Pengertian bangun guna serah disebutkan dalam Pasal 1 angka 12 Peraturan Pemerintah No. 6 Tahun 2006 ${ }^{31}$, yang diubah oleh Pasal 1 angka 12 Peraturan Pemerintah No. 38 Tahun $2008^{32}$ juncto Pasal 1 angka 22 Permendagri No. 17 Tahun $2007^{33}$, yaitu pemanfaatan barang milik negara/daerah berupa tanah oleh pihak lain dengan cara mendirikan bangunan dan/atau sarana berikut fasilitasnya, kemudian didayagunakan oleh pihak lain tersebut dalam jangka waktu yang telah disepakati, untuk selanjutnya diserahkan kembali tanah beserta bangunan dan/atau sarana berikut

29 Pasal 2 ayat (3) Undang-Undang Nomor 20 Tahun 2000 tentang Perubahan atas Undang-Undang Nomor 21 Tahun 1997 tentang Bea Perolehan Hak Atas Tanah dan Bangunan (Lembaran Negara Republik Indonesia Tahun 2000 Nomor 130, Tambahan Lembaran Negara Republik Indonesia Nomor 4048).

30 Pasal 1 Peraturan Pemerintah Nomor 112 Tahun 2000 tentang Pengenaan Bea Perolehan Hak Atas Tanah dan Bangunan Karena Pemberian Hak Pengelolaan (Lembaran Negara Republik Indonesia Tahun 2000 Nomor 214, Tambahan Lembaran Negara Republik Indonesia Nomor 4031).

31 Pasal 1 angka 12 Peraturan Pemerintah Nomor 6 Tahun 2006 tentang Pengelolaan Barang Milik Negara/Daerah (Lembaran Negara Republik Indonesia Tahun 2006 Nomor 20, Tambahan Lembaran Negara Republik Indonesia Nomor 4609).

32 Pasal 1 angka 12 Peraturan Pemerintah Nomor 38 Tahun 2008 tentang Perubahan atas Peraturan Pemerintah Nomor 6 Tahun 2006 tentang Pengelolaan Barang Milik Negara/Daerah (Lembaran Negara Republik Indonesia Tahun 2008 Nomor 78, Tambahan Lembaran Negara Republik Indonesia Nomor 4855 ).

33 Pasal 1 angka 22 Peraturan Menteri Dalam Negeri Nomor 17 Tahun 2007 tentang Pedoman Teknis Pengelolaan Barang Milik Daerah. 
fasilitasnya setelah berakhirnya jangka waktu. Berdasarkan pengertian bangun guna serah menunjukkan bahwa tanah pemerintah kabupaten/kota dapat dimanfaatkan oleh pihak lain dengan cara mendirikan bangunan gedung dan/atau sarana berikut fasilitasnya, kemudian pihak lain mendayagunakan bangunan dan/atau sarana berikutnya fasilitas untuk jangka waktu tertentu berdasarkan kesepakatan kedua belah pihak, dan pada masa akhir perjanjian, tanah dan bangunan, serta sarana berikut fasilitasnya diserahkan kembali oleh pihak lain kepada pemerintah kabupaten/kota. Bangun guna serah antara pemerintah kabupaten/kota dan perusahaan swasta yang berbentuk Perseroan Terbatas dituangkan dalam bentuk perjanjian tertulis.

Berdasarkan uraian di atas menunjukkan bahwa status tanah yang dapat dikuasai oleh pemerintah kabupaten/kota adalah hak pakai dan hak pengelolaan. Dari 2 (dua) status tanah tersebut, status tanah yang dapat menjadi objek perjanjian bangun guna serah antara pemerintah kabupaten/kota dan Perseroan Terbatas adalah tanah yang berstatus hak pengelolaan sebab dalam hak pengelolaan terdapat kewenangan yang diberikan kepada pemegang haknya yaitu menyerahkan bagian-bagian tanah hak pengelolaan kepada pihak ketiga dan atau bekerja sama dengan pihak ketiga. Hak pakai yang dikuasai oleh pemerintah kabupaten/kota tidak dapat menjadi objek Perjanjian Banguna Guna Serah dengan Perseroan Terbatas sebab kewenangan yang diberikan kepada pemerintah kabupaten/kota terhadap tanah hak pakainya adalah mempergunakan tanah untuk kepentingan pelaksanaan tugasnya, tidak ada kewenangan berupa menyerahkan bagianbagian tanah hak pakai kepada pihak ketiga dan atau tidak ada kewenangan bekerja sama dengan pihak ketiga.

Kalau tanah yang dikuasai oleh pemerintah kabupaten/kota berstatus hak pakai dan ingin dijadikan objek Perjanjian Banguna Guna Serah, maka hak pakainya dilepaskan terlebih dahulu oleh pemerintah kabupaten/kota untuk kepentingan Perseroan Terbatas. Dengan pelepasan hak pakai, maka tanah hak pakai menjadi hapus dan tanahnya kembali menjadi tanah negara. Selanjutnya pemerintah kabupaten/kota mengajukan permohonan hak pengelolaan kepada Kepala Badan Pertanahan Nasional RI melalui Kepala Kantor Pertanahan Kabupaten/Kota setempat. Kalau permohonan hak pengelolaan atas tanah negara dikabulkan oleh Kepala Badan Pertanahan Nasional RI dikabulkan, maka Kepala Badan Pertanahan Nasional RI menerbitkan Surat Keputusan Pemberian Hak Pengelolaan. Surat Keputusan Pemberian Hak Pengelolaan disampaikan kepada pemerintah kabupaten/kota sebagai pemohon hak pengelolaan. Selanjutnya pemerintah kabupaten/kota mendaftarkan Surat Keputusan Pemberian Hak Pengelolaan ke Kantor Pertanahan Kabupaten/Kota setempat untuk diterbitkan Sertifikat Hak Pengelolaan sebagai tanda bukti haknya.

\section{Perolehan Hak Atas Tanah oleh Perseroan Terbatas yang Berasal dari Perjanjian Banguna Guna Serah}

Tanah yang dikuasai oleh pemerintah kabupaten/kota dapat dipergunakan untuk kepentingan pelaksanaan tugasnya, atau dapat dipergunakan oleh pihak lain atas persetujuan dari pemerintah kabupaten/kota. Penggunaan tanah pemerintah kabupaten/kota oleh pihak lain dapat disebabkan oleh ketiadaan atau keterbatasan dana yang ada pada Pemerintah kabupaten/kota. Untuk lebih mengoptimalkan dalam penggunaan tanah, pemerintah kabupaten/kota membuat perjanjian kerjasama dengan perusahaan swasta dalam bentuk Perjanjian Banguna Guna Serah. Dalam Perjanjian Banguna Guna Serah disini, perusahaan swasta mendapatkan persetujuan dari pemerintah kabupaten/kota untuk mempergunakan tanah pemerintah kabupaten/kota guna didirikan bangunan gedung.

Bangun guna serah merupakan salah satu bentuk pengelolaan barang milik negara/daerah yang berupa pemanfaatan, yang diatur dalam Peraturan Pemerintah No. 6 Tahun 2006 sebagaimana diubah oleh Peraturan Pemerintah No. 38 Tahun 2008. Macam pemanfaatan barang milik negara/ daerah selain bangun guna serah, adalah persewaan, pinjam pakai, kerjasama pemanfaatan, dan bangun serah guna.

Istilah asing dari bangun guna serah adalah build, operate, and transfer (BOT). Maria S.W. Sumardjono memberikan pengertian build, operate, 
and transfer (BOT), yaitu: "Perjanjian antara dua pihak, dimana pihak pertama menyerahkan penggunaan tanahnya untuk dirikan bangunan di atasnya oleh pihak kedua, dan pihak kedua berhak mengoperasikannya atau mengelola bangunan tersebut dalam jangka waktu tertentu, dengan memberikan fee atau tanpa fee kepada pihak pertama, dan pihak kedua wajib mengembalikan tanah tersebut beserta bangunan di atasnya dalam keadaan dapat dan siap dioperasikan kepada pihak pertama setelah jangka waktu operasional berakhir. ${ }^{34}$

Budi Santoso memberikan pengertian bahwa Perjanjian Build, Operate, and Transfer (BOT), yaitu: "build, operate, and transfer (BOT) tidak lain adalah sebuah kontrak atau perjanjian antara pemilik proyek (pemerintah) dengan pihak lain sebagai operator atau pelaksana proyek. Dalam hal ini pemilik proyek memberikan hak kepada operator atau pelaksana untuk membangun sebuah sarana atau prasarana (umum) serta mengoperasikannya untuk selama jangka waktu tertentu dan mengambil seluruh atau sebagian keuntungan dan pada akhir masa kontrak harus mengembalikan proyek tersebut kepada pemilik proyek. ${ }^{35}$ Perjanjian Banguna Guna Serah atau Build, Operate, and Transfer (BOT) adalah perjanjian yang dibuat oleh pemegang hak pengelolaan dan perusahaan swasta, yang berisi perusahaan swasta diberi hak untuk mempergunakan tanah hak pengelolaan guna didirikan bangunan komersial di atasnya, perusahaan swasta diberi hak untuk meng-operasionalkan atau mempergunakan bangunan tersebut untuk jangka waktu tertentu sesuai kesepakatan kedua belah pihak, dan pada akhir masa perjanjian, bangunan beserta fasilitas pendukungnya diserahkan kembali kepada pemegang hak pengelolaan.

Perjanjian Banguna Guna Serah atau Build, Operate, and Transfer (BOT) terjadi disebabkan oleh keterbatasan atau ketiadaan dana yang ada pada pemegang hak pengelolaan untuk melaksanakan pendirian bangunan. Untuk itu, pemegang hak pengelolaan bekerja sama dengan perusahaan swasta untuk melaksanakan pendirian bangunan. Pemegang hak pengelolaan menyediakan tanahnya, sedangkan pe- rusahaan swasta menyediakan dana dan melaksanakan pendirian bangunan. Hak atas tanah yang diperoleh perusahaan swasta yang berbentuk Perseroan Terbatas, yang berasal dari Perjanjian Bangun Guna Serah atau Build, Operate, and Transfer (BOT) dengan pemerintah kabupaten/kota sebagai pemegang hak pengelolaan adalah hak guna bangunan atau hak pakai yang berasal dari tanah hak pengelolaan. Secara ekonomis, hak atas tanah yang diperoleh dari Perjanjian Banguna Guna Serah atau Build, Operate, and Transfer (BOT) adalah hak guna bangunan daripada hak pakai sebab jangka waktu hak guna bangunan lebih lama daripada hak pakai.

Ketentuan-ketentuan tentang bangun guna serah atau build, operate, and transfer (BOT) yang diatur dalam Peraturan Pemerintah No. 6 Tahun 2006, yang diubah oleh Peraturan Pemerintah No. 38 Tahun 2008 dan Peraturan Menteri Dalam Negeri No. 17 Tahun 2007 adalah:

a. Dasar pertimbangan bangun guna serah barang milik daerah, yaitu:

1) Barang milik daerah belum dimanfaatkan;

2) Mengoptimalkan barang milik daerah;

3) Dalam rangka efisiensi dan efektifitas;

4) Menambah/meningkatkan pendapatan daerah; dan

5) Menunjang program pembangunan dan kemasyarakatan Pemerintah Daerah.

b. Bangun guna serah barang milik daerah dapat dilaksanakan dengan ketentuan sebagai berikut:

1) Pemerintah Daerah memerlukan bangunan dan fasilitas bagi penyelenggaraan pemerintahan daerah untuk pelayanan umum dalam rangka penyelenggaraan tugas pokok dan fungsi;

2) Tanah milik Pemerintah Daerah yang telah diserahkan oleh pengguna kepada Kepala Dae-

Maria S.W. Sumardjono, 2008, Tanah Dalam Perspektif Hak Ekonomi Sosial dan Budaya, Penerbit Kompas, Jakarta, hlm. 208.

Budi Santoso, 2008, Aspek Hukum Pembiayaan Proyek Infrastruktur Dengan Model Build, Oparate, and Transfer, Genta Press, Yogyakarta, hlm. 15-16. 
rah; dan

3)

Tidak tersedia dana Anggaran

Pendapatan dan Belanja Daerah untuk penyediaan bangunan dan fasilitas dimaksud.

c. Bangun guna serah barang milik daerah dilaksanakan oleh pengelola setelah mendapat persetujuan Kepala Daerah.

d. Penggunaan tanah yang dibangun harus sesuai dengan Rencana Tata Ruang Wilayah (RTRW).

e. Penetapan mitra bangun guna serah dilaksanakan melalui tender/lelang dengan mengikutsertakan sekurangkurangnya 5 (lima) peserta/peminat. Apabila diumumkan 2 (dua) kali berturut-turut pemintanya kurang dari 5 (lima), maka dapat dilakukan proses pemilihan langsung atau penunjukan langsung melalui negosiasi baik teknis maupun harga.

f. Biaya pengkajian, penelitian dan pengumuman tender/lelang dibebankan pada Anggaran Pendapatan dan Belanja Daerah.

g. Mitra bangun guna serah yang telah ditetapkan selama jangka waktu pengoperasian harus memenuhi kewajiban sebagai berikut:

1) Membayar kontribusi ke rekening kas umum daerah setiap tahun yang besarannya ditetapkan berdasarkan perhitungan tim yang dibentuk oleh Kepala Daerah;

2) Tidak menjaminkan, menggadaikan atau memindahtangankan objek bangun guna serah;

3) Memelihara objek bangun guna serah.

h. Objek bangun guna serah adalah Sertifikat hak pengelolaan pemerintah kabupaten/kota tidak boleh dijaminkan, digadaikan, dan dipindahtangankan.

i. Mitra bangun guna serah mempunyai kemampuan dan keahlian.

j. Mitra bangun guna serah mendapatkan hak guna bangunan atas tanah hak pengelolaan pemerintah kabupaten/kota.

k. Hak guna bangunan atas tanah hak pengelolaan pemerintah kabupaten/ kota dapat dijadikan jaminan, diagunkan dengan dibebani hak tanggungan.

1. Jangka waktu bangun guna serah paling lama 30 (tiga puluh) tahun sejak perjanjian ditandatangani.

m. Izin mendirikan bangunan bangun guna serah atas nama pemerintah kabupaten/kota.

n. Biaya yang berkenaan dengan persiapan dan pelaksanaan penyusunan surat perjanjian, konsultan pelaksana/pengawas dibebankan pada mitra bangun guna serah.

o. Bangun guna serah dilaksanakan berdasarkan surat perjanjian yang sekurang-kurangnya memuat:

1) Pihak-pihak yang terkait dalam perjanjian;

2) Objek bangun guna serah;

3) Jangka waktu bangun guna serah;

4) Pokok-pokok mengenai bangun guna serah;

5) Tanah-tanah yang menjadi objek bangun guna serah;

6) Hak dan kewajiban para pihak yang terikat dalam perjanjian;

7) Jumlah/besarnya kontribusi yang harus dibayar oleh perusahaan swasta sebagai mitra kerja sama bangun guna serah;

8) Sanksi;

9) Surat perjanjian ditandatangani oleh bupati/walikota dan perusahaan swasta sebagai mitra kerja sama bangun guna serah;

10) Persyaratan lain yang dianggap perlu.

p. Biaya pembangunan dibebankan ke- 
pada perusahaan swasta sebagai mitra kerja sama bangun guna serah.

q. Perusahaan swasta sebagai mitra kerja sama bangun guna serah mempunyai hak untuk mengoperasikan bangunan yang dia bangun selama jangka waktu yang diperjanjikan.

r. Pada masa akhir pengoperasian yang diperjanjikan, bangunan/gedung beserta fasilitas pendukungnya diserahkan oleh perusahaan swasta sebagai mitra kerja sama bangun guna serah kepada Pemerintah Kabupaten/Kota yang dituangkan dalam bentuk berita acara.

Prosedur perolehan hak atas tanah oleh Perseroan Terbatas yang berasal dari Perjanjian Banguna Guna Serah dengan Pemerintah Kabupaten/ Kota, adalah:

\section{a. Pembuatan Perjanjian Banguna \\ Guna Serah atau Build, Operate, and Transfer (BOT)}

Perjanjian Banguna Guna Serah atau Build, Operate, and Transfer (BOT) dibuat antara pemerintah kabupaten/kota sebagai pemegang hak pengelolaan dan perusahaan swasta yang berbentuk Perseroan Terbatas dengan akta autentik yang dibuat oleh notaris atau akta di bawah tangan. Ketentuan-ketentuan yang dimuat dalam Perjanjian Banguna Guna Serah atau Build, Operate, and Transfer (BOT), yaitu:

a) Pemerintah kabupaten/kota sebagai pemegang hak pengelolaan;

b) Perseroan Terbatas;

c) Tanah hak pengelolaan yang menjadi objek Perjanjian Banguna Guna Serah atau Build, Operate, and Transfer (BOT);

d) Hak guna bangunan yang akan diberikan oleh pemerintah kabupaten/kota kepada Perseroan Terbatas;

e) Jangka waktu Perjanjian Bangu- na Guna Serah atau Build, Operate, and Transfer (BOT);

f) Kewajiban pengurusan sertifikat hak pengelolaan apabila tanahnya belum bersertifikat;

g) Kewajiban pengurusan Sertifikat Hak Guna Bangunan atas tanah Hak Pengelolaan;

h) Untuk keperluan bangunan apa di atas Perjanjian Banguna Guna Serah atau Build, Operate, and Transfer (BOT);

i) Hak, kewajiban, dan larangan bagi pemerintah kabupaten/kota dan Perseroan Terbatas;

j) Cara penyelesaian sengketa antara pemerintah kabupaten/ kota dan Perseroan Terbatas.

Dengan telah dibuatnya Perjanjian Banguna Guna Serah atau Build, Operate, and Transfer (BOT) telah lahir hubungan hukum antara pemerintah kabupaten/kota dengan Perseroan Terbatas. Namun demikian, belum lahir hak guna bangunan atas tanah hak pe-ngelolaan bagi Perseroan Terbatas.

\section{b. Penerbitan surat rekomendasi oleh}

Pemerintah Kabupaten/Kota

Pemerintah kabupaten/kota menerbitkan surat rekomendasi kepada Perseroan Terbatas untuk dipergunakan bagi perolehan hak guna bangunan atas tanah hak pengelolaan oleh Perseroan Terbatas.

\section{c. Permohonan pemberian Hak Guna \\ Bangunan atas tanah Hak Pengelo- laan oleh Perseroan Terbatas}

Perseroan Terbatas mengajukan permohonan pemberian hak guna bangunan atas tanah hak pengelolaan pemerintah kabupaten/kota kepada Kepala Kantor Pertanahan Kabupaten/Kota setempat. Dokumen yang disertakan dalam permohonan pemberian hak guna bangunan atas tanah hak pengelolaan pemerintah kabupaten/kota, adalah:

a) Surat permohonan pemberian hak guna bangunan; 
b) Perjanjian Banguna Guna Serah atau Build, Operate, and Transfer (BOT) antara pemerintah kabupaten/kota dan Perseroan Terbatas;

c) Surat rekomendasi yang diterbitkan oleh pemerintah kabupaten/kota;

d) Sertifikat tanah hak pengelolaan pemerintah kabupaten/kota;

e) Bukti identitas diri yang masih berlaku dari Perseroan Terbatas.

\section{d. Penerbitan Surat Keputusan Pem- berian Hak (SKPH)}

Kalau semua persyaratan dalam permohonan pemberian hak guna bangunan atas tanah hak pengelolaan dipenuhi oleh Perseroan Terbatas selaku pemohon, maka Kepala Kantor Pertanahan Kabupaten/Kota setempat menerbitkan Surat Keputusan Pemberian Hak Guna Bangunan atas tanah hak pengelolaan. Dengan telah diterbitkan Surat Keputusan Pemberian Hak Guna Bangunan atas tanah hak pengelolaan, belum lahir hak guna bangunan atas tanah hak pengelolaan.

\section{e. Penerbitan Sertifikat Hak Guna Bangunan atas tanah Hak Pengelo- laan}

Perseroan Terbatas berkewajiban mendaftarkan Surat Keputusan Pemberian Hak Guna Bangunan atas tanah hak pengelolaan dalam waktu yang ditentukan kepada Kepala Kantor Pertanahan Kabupaten/Kota setempat untuk dicatat dalam buku tanah dan diterbitkan Sertifikat Hak Guna Bangunan atas tanah Hak Pengelolaan sebagai tanda bukti haknya. Perolehan hak guna bangunan atas tanah hak pengelolaan oleh Perseroan Terbatas yang berasal dari Perjanjian Banguna Guna Serah atau Build, Operate, and Transfer (BOT) dengan pemerintah kabupaten/kota melalui permohonan pemberian hak guna bangunan atas tanah Hak Pengelolaan kepada Kepala Kantor Pertanahan Kabupaten/Kota. Atas permohonan tersebut, oleh
Kepala Kantor Pertanahan Kabupaten/Kota setempat diterbitkan Surat Keputusan Pemberian Hak Guna Bangunan atas tanah Hak Pengelolaan. Surat Keputusan Pemberian Hak Guna Bangunan atas tanah Hak Pengelolaan wajib didaftarkan oleh Perseroan Terbatas ke Kantor Pertanahan Kabupaten/ Kota setempat untuk dicatat dalam buku tanah dan diterbitkan Sertifikat Hak Guna Bangunan atas tanah Hak Pengelolaan sebagai tanda bukti haknya.

\section{Penutup}

Status tanah yang dapat dikuasai oleh pemerintah kabupaten/kota sebagai barang milik daerah adalah hak pakai dan hak pengelolaan. Dari 2 (dua) macam status tanah tersebut, status tanah yang dapat menjadi objek Perjanjian Banguna Guna Serah adalah hak pengelolaan sebab dalam hak pengelolaan terdapat kewenangan berupa menyerahkan bagian-bagian tanah hak pengelolaan kepada pihak ketiga dan atau bekerja sama dengan pihak ketiga. Kewenangan yang terdapat dalam hak pakai yang dikuasai oleh pemerintah kabupaten/kota adalah mempergunakan tanah hak pakai untuk kepentingan pelaksanaan tugasnya.

Cara perolehan hak atas tanah oleh Perseroan Terbatas yang berasal dari Perjanjian Banguna Guna Serah dengan pemerintah kabupaten/kota adalah dengan Penetapan Pemerintah melalui permohonan pemberian hak guna bangunan atas tanah hak pengelolaan pemerintah kabupaten/kota kepada Kepala Kantor Pertanahan Kabupaten/Kota setempat. Atas permohonan pemberian hak atas tanah tersebut, Kepala Kantor Pertanahan Kabupaten/ Kota setempat menerbitkan Surat Keputusan Pemberian Hak (SKPH). SKPH wajib didaftarkan ke Kantor Pertanahan Kabupaten/Kota setempat untuk dicatat dalam buku tanah dan diterbitkan Sertifikat Hak Guna Bangunan atas tanah Hak Pengelolaan sebagai tanda bukti haknya. 


\section{DAFTAR PUSTAKA}

\section{A. Buku}

Ishaq, Februari, 2008, Dasar-Dasar Ilmu Hukum, Sinar Grafika, Jakarta.

Parlindungan, A.P., Menurut Sistem Undang-Undang Pokok Agraria, Mandar Maju, Bandung.

Santoso, Budi, 2008, Aspek Hukum Pembiayaan Proyek Infrastruktur dengan Model Build, Oparate, and Transfer, Genta Press, Yogyakarta.

Santoso,Urip, 2012, Hukum Agraria Kajian Komprehensif, Kencana Prenada Media, Jakarta.

Soeroso, R., 1993, Pengantar Ilmu Hukum, Sinar Grafika, Jakarta.

Sumardjono, Maria S.W., 2007, Kebijakan Pertanahan antara Regulasi dan Implementasi, Kompas, Jakarta.

Supriadi, 2007, Hukum Agraria, Sinar Grafika, Jakarta.

\section{B. Artikel Majalah, Jurnal}

Parlindungan, A.P., "Beberapa Konsep Tentang Hak Atas Tanah", Majalah Analisis CSIS Tahun XX No. 2, Maret - April 1991.

Santoso, "Eksistensi Hak Pengelolaan Dalam Hukum Tanah Nasional", Jurnal Mimbar Hukum, Vol. 24, No. 2, Juni 2012.

\section{Artikel Pidato Penerimaan Jabatan}

Hajati, Sri, "Retrukturisasi Hak Atas Tanah Dalam Rangka Pembaruan Hukum Agraria Nasional", Pidato, Penerimaan Jabatan Guru Besar pada Universitas Airlangga, Surabaya, $5 \mathrm{Ma}$ ret 205 .

\section{Peraturan Perundang-Undangan}

Undang-Undang No. 5 Tahun 1960 tentang Peraturan Dasar Pokok-pokok Agraria (Lembaran Negara Republik Indonesia Tahun 1960 Nomor 104, Tambahan Lembaran Negara Republik Indonesia Nomor 2043).

Undang-Undang No. 20 Tahun 2000 tentang Perubahan Atas Undang-undang Nomor 21 Tahun
1997 tentang Bea Perolehan Hak Atas Tanah dan Bangunan (Lembaran Negara Republik Indonesia Tahun 2000 Nomor 130, Tambahan Lembaran Negara Republik Indonesia Nomor 4048).

Peraturan Pemerintah No. 40 Tahun 1996 tentang Hak Guna Usaha, Hak Guna Bangunan, dan Hak Pakai Atas Tanah (Lembaran Negara Republik Indonesia Tahun 1996 Nomor 58, Tambahan Lembaran Negara Republik Indonesia Nomor 3643 ).

Peraturan Pemerintah No. 24 Tahun 1997 tentang Pendaftaran Tanah (Lembaran Negara Republik Indonesia Tahun 1997 Nomor 59, Tambahan Lembaran Negara Republik Indonesia Nomor 3696).

Peraturan Pemerintah No. 112 Tahun 2000 tentang Pengenaan Bea Perolehan Hak Atas Tanah dan Bangunan Karena Pemberian Hak Pengelolaan (Lembaran Negara Republik Indonesia Tahun 2000 Nomor 214, Tambahan Lembaran Negara Republik Indonesia Nomor 4031).

Peraturan Pemerintah No. 6 Tahun 2006 tentang Pengelolaan Barang Milik Negara/Daerah (Lembaran Negara Tahun 2006 Nomor 20, Tambahan Lembaran Negara Republik Indonesia Nomor 4609).

Peraturan Pemerintah No. 38 Tahun 2008 tentang Perubahan Atas Peraturan Pemerintah Nomor 6 Tahun 2006 tentang Pengelolaan Barang Milik Negara/Daerah (Lembaran Negara Tahun 2008 Nomor 78, Tambahan Lembaran Negara Republik Indonesia Nomor 4855).

Peraturan Pemerintah No. 11 Tahun 2010 tentang Penertiban dan Pendayagunaan Tanah Terlantar (Lembaran Negara Tahun 2010 Nomor 16 , Tambahan Lembaran Negara Republik Indonesia Nomor 5098).

Peraturan Menteri Agraria No. 9 Tahun 1965 tentang Konversi Hak Penguasaan Atas Tanah Negara dan Ketentuan-Ketentuan tentang 
Kebijaksanaan Selanjutnya.

Peraturan Menteri Agraria No. 9 Tahun 1966 tentang Pendaftaran Hak Pakai dan Hak Pengelolaan.

Peraturan Menteri Negara Agraria/Kepala Badan Pertanahan Nasional No. 9 Tahun 1999 tentang Tata Cara Pemberian dan Pembatalan
Pemberian Hak Atas Tanah Negara dan Hak Pengelolaan.

Peraturan Menteri Dalam Negeri No. 17 Tahun 2007 tentang Pedoman Teknis Pengelolaan Barang Milik Daerah. 